\title{
Establishing Contact: Slavonic Influence on Romanian Morphology?
}

\author{
Martin Maiden \\ Statutory Professor of the Romance Languages Research Centre for Romance \\ Linguistics, Faculty of Linguistics, Philology, and Phonetics and Faculty of \\ Medieval and Modern Languages, University of Oxford, Oxford, UK \\ martin.maiden@mod-langs.ox.ac.uk
}

\begin{abstract}
It is not disputed that Slavonic languages have influenced the inflexional morphology of Romanian and its closely related Daco-Romance varieties. For example, Romanian vocatives in -o, Istro-Romanian perfective verb-roots, and probably the MeglenoRomanian first and second person singular endings -um and -if, are all attributable to Slavonic. These cases generally involve loans of 'morpheme'-like entities, phonological strings associated with a particular grammatical meaning. However, it has recently been suggested (e.g., by Elson, 2017) that certain Romanian paradigmatic patterns of root allomorphy in the verb, notably those involving the effects of palatalization, are influenced by Slavonic models. Some of these patterns appear to be of a qualitatively different kind from run-of-the-mill 'morphemic' loans, in that they are autonomously morphological, and cannot be associated within any coherent grammatical meaning. The borrowing of such purely morphological patterns under conditions of language contact has not hitherto been attested in the literature on language contact, and the evidence for such cases in Romanian deserves careful scrutiny. Unfortunately, the arguments provided for these putative borrowings can be shown to be rest on seriously flawed assumptions. Examination of those arguments serves to focus our attention on the kind of criteria that need generally to be met if the effects of language contact in morphology (or any other domain) are to be plausibly demonstrated. In particular, I shall emphasize the need for appeals to language contact carefully to exploit the full range of available comparative evidence, and to establish rigorous criteria to exclude the possibility that apparent contact effects are explicable by factors internal to the history of the recipient language.
\end{abstract}




\section{Keywords}

Romanian - Bulgarian - paradigms - morphomes - diachrony - comparative

\section{An Alleged Bulgarian Influence on Daco-Romance Verb Morphology}

Romanian verb morphology shows some deviations from the historically predicted development, and these are attributed by Elson (2017) to the effect of early contact with 'middle Bulgarian'. While Romanian verbs with root-final dentals show an expected and regular effect of palatalization by proto-Romance yod in the first person singular present indicative, they fail to do so in the third person plural present indicative. Table (1) demonstrates this, where Latin unstressed front vowels (I or E) before a vowel yield yod ([j]) in proto-Romance, which in turn produces palatalizing and affricating effects on preceding dental consonants. This 'yod effect' (hereafter, $\mathrm{YE}$ ) is predicted for the first person singular present indicative and for the third person plural present indicative. While it is duly observed in the former case, it is surprisingly absent (as indicated by '?' in Table 1) in the latter, in old and modern dialectal Romanian. ${ }^{2}$

The other unexpected deviation from regular sound change which Elson discusses is the fact that proto-Romance root-final velars wholly fail to show expected YE in the first person singular present indicative and in third person plural present indicative (Table 2). The phonetically regular outcome is an affricate [ts], [d] (cf. socium > soț 'husband'; *'fakja > față 'face'; ABSUn GIAM $>$ osânză 'lard'), but what we systematically find in the verb is an apparently unmodified velar [k], [g]; again, the aberrant forms are indicated with '?.

Elson (2017: 88gf.) believes that such facts show Romanian to have:

reorganized the pattern of allomorphic variation attested in the present system of verbs with radical-final dental, which, in Bulgarian, opposed the first person singular to the other forms, and velar, which opposed the first person singular and third person plural to the remaining forms [...] In other words, it adopted an organizational, or systemic, attribute of Bulgarian

1 For the status of the glottonym '(middle) Bulgarian', I refer readers to Elson's study, and particularly Elson (2017: $848 \mathrm{nul} ; 868 \mathrm{n} 4 \mathrm{O}$ ). I use here the term 'Slavonic' to refer to the entire language family, rather than solely to Old Church Slavonic.

2 In fact, the yod effect is not limited to the present tense, occurring also in the third person forms of the subjunctive. I return to this point later, but here follow Elson in focusing on the present. 


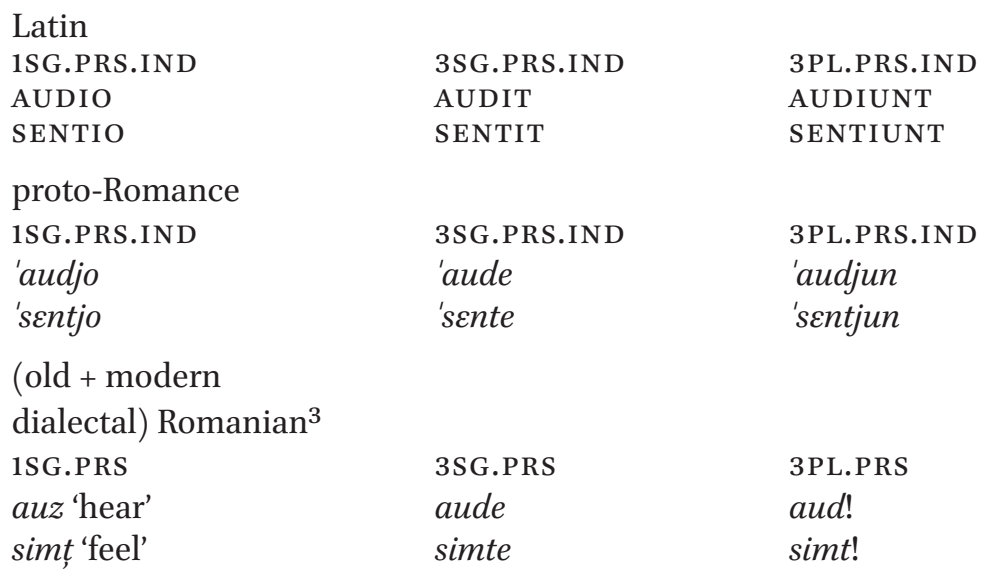

TABLE 2 Apparent lack of yod effect on velars in the Romanian verb

\begin{tabular}{lll}
\hline Latin & & \\
1SG.PRS & 3SG.PRS & 3PL.PRS \\
FACIO & FACIT & FACIUNT \\
FUGIO & FUGIT & FUGIUNT \\
'proto-Romance' & & \\
1SG.PRS.IND & 3SG.PRS.IND & 3PL.PRS.IND \\
'fakjo & 'fake & 'fakjun \\
'fugjo & 'fuge & 'fugjun \\
Romanian & & \\
1SG.PRS & & 3 PL.PRS \\
fac! 'do' & 3SG.PRS & fac! \\
fug! 'flee' & face & fug! \\
& fuge &
\end{tabular}

conjugation. [...] We may therefore see, in support of Bulgarian influence in the Romanian present system, a general tendency for the importation of Bulgarian organization into Romanian verbal morphology [...].

This is a claim with intriguing implications for the typology of contact effects. The grounds for making it are as follows: Elson (2017: 879) discerns as the

3 Suffice it to say here that orthographic $z(=[\mathrm{z}])$ continues an earlier affricate [d]; the letter $t$, stands for [ts]. For details of the phonological history of these forms, see e.g., Sala (1976: 120-36). 
TABLE 3 Middle Bulgarian models alleged to have influenced old Romanian present tense alternations $(\check{c}=[\mathrm{t}])$

\begin{tabular}{|c|c|c|c|c|}
\hline (a) & middle Bulgarian & old Romanian & $\begin{array}{l}\text { (b) middle } \\
\text { Bulgarian }\end{array}$ & old Romanian \\
\hline is & $\begin{array}{l}\text { vižd } d_{-a}\left(<{ }^{*} v i d-y-o<\right. \\
\text { *vid-i-o) 'see' }\end{array}$ & vădzu 'see' & reka 'say' & $f a[\mathrm{k}] u^{\prime}$ 'do' \\
\hline $2 \mathrm{~s}$ & vidiš & $v e d z i$ & rečeš & $f a[\mathrm{t}]] i$ \\
\hline $3 s$ & vidi & veade & reče & $f a[\mathrm{t}] e$ \\
\hline ip & vidim & vedem & rečem & fa[t]em \\
\hline $2 \mathrm{p}$ & vidite & vedeți & rečete & $f a[\mathrm{t}] e t ̦ i$ \\
\hline $3 p$ & videt & $v a ̆ d u$ & rekat & $f a[\mathrm{k}] u$ \\
\hline
\end{tabular}

model for the two Romanian patterns the 'middle Bulgarian' present indicative conjugations of vid-i 'see' and of reč-e 'say' (Table 3). The first person singular form of the middle Bulgarian verb 'see' shows the effects of 'palatalization' of a root-final dental, leaving that consonant intact in the rest of the present paradigm, while in the verb 'say', an effect known as 'softening' of velar consonants has applied throughout the present tense, save in the first person singular and third person plural, ${ }^{4}$ where the conditioning environment is historically lacking.

According to Elson (2017: 869), the mechanisms behind the Romanian facts are as follows: 5

we may assume that the Bulgarian present indicative distribution of paradigmatic * $y$ vis-à-vis radical-final dental versus velar was imported into

4 The emergence of the alternant $d z$ also in the second person singular is a historically separate phenomenon and certainly later than the yod effect.

5 There is a serious chronological problem with Elson's assumption that the phenomenon occurred 'preceding or during the Romance yotation', in that the Romance palatalization by yod was operative as early as the second century (Väänänen, 1963: 54-56), and indeed is a pan-Romance phenomenon, while it is by no means obvious that it was still productive by the time the Slavs came into contact with the Romance speakers. Elson himself recognizes as much (2017: $869 \mathrm{n} 4 \mathrm{O}$ ), yet then takes the illegitimate step of trying to salvage his hypothesis by suggesting, without independent motivation, that the date of contact between the two linguistic groups must have been earlier than is generally assumed. Fortunately, he also more plausibly suggests that his analysis could be recast in terms of the existing reflexes of palatalization - and this is surely the only safe way to approach the facts. 
Romanian preceding or during the Romance yotation, and perhaps softening as well, yielding the distribution of reflexes of yotation we find in the contemporary language $[\ldots]$.

He further writes (Elson, 2017: 870) that

all verbs with radical-final dental have a reflex [of the effect of yod] in in the first person singular, and only in that form, while all verbs with radical-final velar [...] lack a reflex in both the first person singular and third person plural. This consistency [...] follows from the Bulgarian distribution, which was instantiated regularly: intra-paradigmatic * $y$ occurred in the first person singular of all verbs with radical-final dental, but in none with radical-final velar.

We shall see that, in reality, the evidence for 'Bulgarian' influence is very weak. First, however, we need to consider the theoretical significance of Elson's hypothesis.

\section{Theoretical Significance of the 'Bulgarian' Hypothesis}

\subsection{Typology of Slavonic Influences on Romanian}

It is uncontroversial that the prolonged contact in the Middle Ages (perhaps from the sixth century until the twelfth) between Romanian and Slavonic determined significant changes in the former (see, e.g., Rosetti, 1986: 263-320; Sala, 2013: 214-226). There has been obvious and extensive lexical borrowing, which penetrated quite basic semantic domains, such as the names of body parts (e.g., gleznă 'ankle', obraz 'cheek'), including 'semantic calquing', as in the words picior and mână which, although undoubtedly of Latin origin (from PETIOLUS 'stalk' and MANUS 'hand'), have acquired a typically Slavonic pattern of reference in that they denote, respectively, the entirety of the upper and of the lower limb, without differentiating 'foot' from 'leg' and 'hand' from 'arm'. In the domain of morphology, ${ }^{6}$ there is also considerable borrowing (cf. Rosetti, 1986: 278-282; Petrucci, 1999: 90-135), especially involving derivational affixes. Just a few examples are: the iterative prefix răs- (e.g., a răsciti 'to read and re-read'), the adjectival or agentive suffix -nic (e.g., obraznic 'cheeky',

6 Syntactic influences from Slavonic are widely assumed, if controversial (see, e.g., Dragomirescu, 2015). 
zilnic 'daily'), feminine diminutive or agentive -iță (e.g., fetița 'little girl', actriță 'actress'), feminine ethnic -că (e.g., româncă 'Romanian woman').

Slavonic influence on Romanian inflexional morphology is less evident (cf. Sala, 2013: 216). An incontestable case involves the ending -o which is available to form the vocative of words ending in - $\breve{a}$ (the overwhelming majority of them feminine), such as fată 'girl', vocative fato. A classic example first brought to prominence by Weinreich (1968), involves the Megleno-Romanian desinences 1SG -um, 2SG -if, which are apparently borrowed from Macedonian. These are described as 'undisputably' Slavonic by Elson (2017: 886), although their status as a Slavonic loan has in fact been seriously disputed (Friedman, 2009). ${ }^{7}$ An eye-catching source of innovation in inflexional morphology is the creation, under Croatian linguistic influence, of morphological aspect distinctions throughout the paradigm of the verb in Istro-Romanian dialects, by means of borrowing of affixes or indeed of entire lexemes in order to furnish a full set of distinctively perfective forms in opposition to the imperfective (see, e.g., Kovačec, 1971: 123-130; Sala, 2013: 222f.; Maiden, 2016a: 111). ${ }^{8}$

What all the generally acknowledged and indisputable examples of Slavonic influence on Daco-Romance morphology share is their 'concreteness': they usually involve readily segmentable pieces of morphological structure (affixes or inflexional desinences) associated with clearly defined derivational meanings or grammatical functions, and in this respect they are rather like traditional lexical borrowings. In traditional terms, they might be viewed as different from the latter only in the respect that they are 'bound morphemes'. The Istro-Romanian case mentioned above involves the importation of a variety of devices as markers of paradigmatic opposition, but they are 'concrete' in the sense that they can be generally identified as markers of a particular value for aspect. The examples given in Elson (2017) are of a kind significantly different from all the foregoing, a type which he calls 'realizational'. Elson (2017: 888) writes:

When innovation in morphological systems is realizational $[\ldots]$ there are no new forms, but only changes in the phonemic composition of existing ones. We therefore, perhaps understandably, find a strong tendency among linguists to interpret such compositional changes as the result of non-phonetic innovation in the form of analogy, i.e., as the result of system-internal innovation with no regard to the defensibility of its in-

7 See also Kossmann (2015: 259f.).

8 See Hurren (1969) for a more detailed account of the various aspectual values marked in the Istro-Romanian verb. 
vocation (i.e., whether there was an existing pattern which might have served as the basis for the changes in phonemic composition). It is in such situations that we must give serious consideration to contact [...]

What is at issue is a matter of imposition on Romanian of Bulgarian patterns of paradigmatic distribution, instead of the expected and phonologically regular patterns. ${ }^{9}$ One of these patterns (Table $3(\mathrm{~b})$ ) pertains to an opposition between the alternants $[\mathrm{t}]$ and $[\mathrm{k}]$, whose paradigmatic distribution is defined (for Bulgarian) over a set of cells which is irreducible to any common semantic or functional denominator, and whose content actually involves opposite values (singular vs plural, and third person vs first person), while being arbitrarily confined to the present tense (other tenses do not show this alternation). No coherent 'meaning' can be assigned to these alternants, and their paradigmatic domain is synchronically arbitrary. The same is true, albeit rather less obviously, for the type of alternation exemplified in Table 3 (a). The opposition involved here involves the combination of values 'first person' and 'singular', which might be regarded as expressing EGO, but the fact that it is confined just to the present tense (other first person singular forms do not show the alternant in the relevant verbs) again confers on it an idiosyncratic paradigmatic distribution. Both these 'realizational' occurrences probably qualify as 'morphomic' (cf. Aronoff, 1994), ${ }^{10}$ in that they are defined over 'irreducibly heterogeneous feature combinations' Maiden (2018: 20). ${ }^{11}$ They cannot, that is to say, be assigned any coherent function and they are, in that sense, 'autonomously morphological', having no synchronic motivation outside the morphology itself. Maiden (2018: 22) also specifies a particular, typological, criterion for the identification of a morphomic structure:

An important criterion for morphomic status is local uniqueness. [...] morphomic structures are virtually always the local, fortuitous, cumulative effects of other (often phonological) changes. Precisely because they

9 Elson's contrast between 'realizational' and the 'incremental' (addition of new forms) uses two well-established terms in morphological theory in a quite different way from what has come normally to be understood by them (see, e.g., Stump, 2001: 2).

10 I do not mean to suggest that 'realizational', in Elson's sense, and 'morphomic', in mine, are synonymous. My interest here is specifically in certain of the phenomena identified by him as 'realizational' which seem to me also to be morphomic.

11 'Potentially' in that, as Maiden goes on to argue, the psychological reality of a putative morphomic structure can only be guaranteed when speakers implement some change which replicates the pattern. In the present case, the very fact of borrowing might count as such a change. 
tend to reflect the combined effects of more than one extramorphologically motivated change, it is highly unlikely that the same pattern will recur in any other language. If one does find the same pattern in a different language with a different history, and if one can rule out shared inheritance (or language contact: see Chapter 7), then we may suspect a shared extramorphological motivation for the phenomenon, even if it is not entirely clear to us what that motivation might be. [...] An unambiguously morphomic structure is unlikely ever to exist independently in two, let alone more, unrelated [...] languages.

Despite the parenthetical allusion in the foregoing quotation to language contact' as a possible source of the appearance of a morphomic structures in languages that are unrelated, ${ }^{12}$ the case that I actually allude to in the quotation above is not a matter of direct borrowing of a morphomic structure, but of borrowing from Romance into Germanic of a syntactic construction which subsequently gives rise to a morphomic distribution in both language-families, effectively as a result of grammaticalization (see Maiden, 2018: 252). What is involved is the emergence of the 'past participle', as morphomically distributed over both passive and perfective constructions. In contrast, and to the very best of my knowledge, nothing quite like what Elson claims, implying (in my terms) morphomically distributed alternant patterns, is attested anywhere else in the literature on morphological borrowing. ${ }^{13}$ For example, the wide-ranging overviews of borrowing in inflexional morphology provided by Kossmann (2015) or Gardani (2018) mention nothing similar. ${ }^{14}$ It is for this reason that Elson's claims acquire especial theoretical interest. Can morphomic patterns-inherently arbitrary and synchronically 'nonsensical' as they are-really be transferred under conditions of language contact?

I need to anticipate a disappointing conclusion: we shall see that there is simply no good reason to believe that the phenomena presented in Section 1 owe anything to contact with 'middle Bulgarian', despite Elson's claims. Consequently, nothing will be added here to our understanding of morphomic structures in language contact. Rather, the process of testing the correctness of the notion that these might be effects of contact will focus our minds on some essential desiderata for establishing that any linguistic phenomenon is

12 In the case of Romance and Slavonic, the contact languages are related, but only distantly.

13 Although see Gardani et al. (2015: 13) for a case of apparent borrowing of inflexion-class marking.

14 Gardani clearly distinguishes 'abstract' patterning in borrowing, but what is principally involved (Gardani, 2018: 4f.; 10-12) is the ordering of constituents in compounds and is, in a sense, 'syntactic'. 
an effect of contact. We may begin by setting out some common sense requirements for the construction of a plausible argument for contact (Section 2.2).

\subsection{Conditions on Plausible Arguments for Contact Effects}

Certain fairly obvious conditions need to be fulfilled if we are to present a cogent and plausible argument for some linguistic phenomenon $\mathrm{X}$ in language $\mathrm{R}$ being an effect of contact with language B. ${ }^{15}$

i. X must demonstrably exist in B at the time of contact with $\mathrm{R}$.

ii. The manifestation of $\mathrm{X}$ in language $\mathrm{R}$ should be the same as its manifestation in language $\mathrm{B}$ : if $\mathrm{X}$ in language $\mathrm{R}$ is identical in fine detail to something in language $\mathrm{B}$, then contact may plausibly be assumed; if the manifestation of $\mathrm{X}$ in language $\mathrm{R}$ is only 'rather like' some phenomenon in language $\mathrm{B}$, the case for $\mathrm{X}$ as a contact effect is weakened.

iii. $X$ should be unique to $B$ and $R$ : if $X$ also appears in sister varieties of $R$ (let us call them I and G), which have never been in contact with B, then the case for $\mathrm{X}$ as due to contact with $\mathrm{B}$ is very seriously weakened, and it becomes likely that $\mathrm{X}$ is an independent development in language $\mathrm{R}$ and its family, and only coincidentally resembles what we find in B.

Of course, none of the above are necessary conditions for $\mathrm{X}$ to be a result of contact between $\mathrm{R}$ and $\mathrm{B} .{ }^{16}$ They are, however, the kind of conditions that must be met if we are to articulate a plausible case for a contact effect. ${ }^{17}$ If they are not met, then the claim that $\mathrm{X}$ is an effect of contact becomes mere speculation, of little or no scientific value. Elson's arguments as given in Section 1, theoretically suggestive as they are, ultimately underscore the importance of meeting such conditions - because they simply fail to satisfy (iii) and fall some way short of satisfying (ii). We see why in what follows.

The Romanian Phenomena are not Unique to Romanian among Romance Languages

Elson (2017) is clearly aware of the need to satisfy what I have called condition (iii) above. His argument is indeed that the sister varieties of Romanian,

15 The labels ' $\mathrm{B}$ ' and ' $\mathrm{R}$ ' are intended to be arbitrary and thus cross-linguistically valid, but they are also obviously inspired in our case by 'Romanian' and (middle) 'Bulgarian'. And 'I' and ' $G$ ' below can also particularly be interpreted as standing for Italo-Romance and Gallo-Romance, as will become apparent.

16 See also Elson (2017: 89of.).

17 Compare also the criteria proposed by Ascoli (1881-1882) for demonstrating substrate influences. 
belonging to a group of languages descended from what he calls 'ProtoEast-Romance', do not show the phenomena at issue, that they are therefore unique to Romanian within that group of languages, and that it is therefore legitimate to seek the origins of these phenomena in some circumstance peculiar to Romanian. That circumstance is identified as contact with middle Bulgarian, in which language he discerns morphological patterns very similar to what we find in Romanian.

Now, whether there ever was such a thing as 'Proto-East-Romance' is highly dubious, and the label 'East-Romance' is probably more a geographical expression than an early node in the branching of the Romance languages (cf. Malkiel, 1991; Bossong, 2016: 71). Elson's use of the label is also unnecessarily restrictive: the occurrence of the relevant phenomena in any Romance language other than Romanian would seriously weaken the argument, given that no other Romance language was in contact with 'middle Bulgarian'. ${ }^{18}$ However that may be, the definition which Elson provides of 'Proto-East-Romance' ignores vast quantities of relevant historical-comparative data, and thereby wholly distorts the picture. 'Proto-East-Romance' is defined by him as 'the form of Romance recoverable through comparative reconstruction limited to Italian and Romanian' (Elson, 2017:846 n5). In fact, to do any kind of responsible 'comparative reconstruction' we always need to explore and exploit the full range of comparative data available. Whatever 'Proto-East-Romance' might be, it must surely comprise at least the entire Italo-Romance linguistic domain, of which 'Italian' is merely a fragment, one face in an extremely diverse crowd of linguistic varieties, and specifically a form of Florentine Tuscan. ${ }^{19}$ To treat 'Italian' as somehow constituting the complement, within 'Proto-EastRomance', of Romanian, ${ }^{20}$ is an elementary error almost guaranteed to be fatal. Yet Elson (2017: 869) sets up a simple dichotomy between the 'Romanian distribution and its deviation from the expected distribution, attested in Italian' [my emphasis]. The consequences are predictably infelicitous. ${ }^{21}$

18 One would imagine that Dalmatian (cf. Maiden, 2016b) would also count as belonging to 'Proto-East-Romance', and it has clearly been in contact from an early date with Slavonic, but the the available data do not allow us to observe possible parallels with Romanian in the relevant respects.

19 This is an oft-unheeded truth constantly repeated in manuals of Romance or Italian linguistics (e.g., Harris, 1988: 18f.; Maiden, 1995: 3-5).

20 In the relevant respects, what we see for 'Romanian' does happen to be valid for all Romanian's sister Daco-Romance varieties, however.

21 The only non-Italian Italo-Romance form which Elson mentions is facciono (Elson, 2017: 836), but it is presented as the 'Italian' reflex of FACIUNT 'they make' (although the Italian form is fanno). I am unaware that anything like it has ever been attested in Italian 
TABLE 4 Resemblance between first person singular and third person plural present indicative forms in old Italian

\begin{tabular}{lllll}
\hline 1SG.PRS & 3PL.PRS & & 1SG.PRS & 3PL.PRS \\
\hline CREDO & CREDUNT & $>$ & credo & credono \\
MITTO & MITTUNT & $>$ & metto & mettono \\
UENIO & UENIUNT & $>$ & vegno & vegnono
\end{tabular}

The 'expected distribution, attested in Italian', projected to be the norm for 'Proto-East-Romance', has, in Elson's analysis, a rather complex, and specifically morphological, origin. The appearance, allegedly normal for 'Proto-EastRomance', of the palatal alternant in the third person plural present indicative (as well as in the present subjunctive and first person plural present indicative), is explicable, Elson believes (2017: $865 \mathrm{n}_{3} 6$ ), from 'the obvious segmental relationship between the first person singular and the third person plural in the $\breve{\mathrm{E}}$ and I conjugations' in Italian. Examples of the relevant kind are as in Table 4 . On this basis, original second conjugation verbs were then allegedly remodelled (implicitly, at some early stage of the alleged branch of Romance) so that their third person plural present indicative form was also made to contain the form of the first person singular present indicative, in the manner shown in Table 5 .

Now what is allegedly an 'obvious segmental relationship' just vanishes if one takes proper account of the comparative Italo-Romance data. Indeed, a mere glance at a major linguistic atlas of Italy, such as the AIS, instantly makes 'obvious' a very different state of affairs indeed. The presence of the palatal ${ }^{22}$ alternant in the third person plural is characteristic not just of 'Italian' (and of Tuscan), but of most of the dialects of the Rome-Ancona corridor (Lazio, Umbria, parts of the Marche). Yet in these latter dialects, unlike 'Italian', the third person plural does not, and never did, subsume the form of the first person singular. Here (a) the third person plural originally ended in -u vs first person

or medieval Florentine. It is observable in some medieval texts from Umbria (principally the Statuto del Comune e del Popolo di Perugia del 1342 in volgare), and-very marginally-also from Tuscany (data from $O V I$ ).

22 In some cases the presence of a velar alternant overlies an earlier palatal. See, e.g., Maiden (1995: 137). 
TABLE 5 Alleged analogical mechanism for the introduction of palatalized root-allomorphs into the old Italian third person plural present indicative

\begin{tabular}{lllll}
\hline 1SG.PRS & 3PL.PRS & & 1SG.PRS & 3PL.PRS \\
\hline UIDEO & UIDENT & $>$ & veggio & $?=$ veggiono \\
TACEO & TACENT & $>$ & taccio & $?=$ tacciono \\
PLACEO & PLACENT & $>$ & piaccio & $?=$ piacciono \\
UALEO & UALENT & $>$ & vaglio & $?=$ vagliono \\
\hline
\end{tabular}

TABLE 6 Palatalized alternants (or their reflexes) in central Italian first person singular and third person plural present indicative

\begin{tabular}{|c|c|c|c|c|c|}
\hline \multicolumn{3}{|l|}{ Norcia } & \multicolumn{3}{|l|}{ Rieti } \\
\hline 1SG.PRS & 3PL.PRS & & 1SG.PRS & 3PL.PRS & \\
\hline 'vยทgo & 'vjeygu & 'come' & 'beygo & 'beygu & 'come' \\
\hline 'vэjjo & 'vwojju & 'want' & 'bวко & 'boКu & 'want' \\
\hline 'sattoo & 'sattfu & 'know' & 'pottsa & 'pottsu & ‘can' \\
\hline 'vejjo & 'vijju & 'see’ & 'moro & 'moru & 'die' \\
\hline 'beo & 'biu & 'drink' & 'edo & 'idu & 'see' \\
\hline 'kojjo & 'kwojju & 'gather' & & & \\
\hline
\end{tabular}

Ascrea

1SG.PRS

3PL.PRS

'weygo

'weygu

'come'

'teygo

'teygu

'hold'

'pottso

'pottsu

'can'

'woKo

óर́u

'want'

singular in -o, and, (b) -u caused metaphonic raising or diphthongization of the stressed vowel in the third person plural (cf. Merlo, 19o9; Loporcaro and Paciaroni, 2016: 236). Typical examples are given by AIS maps 1661, 1695, 1696, 1699, for points 576 (Norcia, in Umbria) and 624 (Rieti, in Lazio), and from Fanti (1939) for the dialect of Ascrea (Table 6).

Such examples can be multiplied ad libitum for dialects of this area, and they show quite clearly that the presence of the palatal alternant in the third person plural present indicative cannot be an effect of a general pattern of identity between that form and the first person singular, as Elson claims, since 
no such identity ever existed in the relevant dialects. Final -u as a third person plural marker is a direct reflex of Latin -UNT, and its presence is detectable over vast areas of the central and southern Italo-Romance domain; indeed it may once have been general in Italo-Romance. As for metaphony, it is a phenomenon detectable practically throughout Italo-Romance (see, e.g., Maiden, 1991; 2016c), and clearly one of great antiquity. The allegedly 'obvious' pattern discernible in Italian is a local feature of Tuscan varieties, and cannot plausibly be projected onto 'Proto-East-Romance'.

That the specific explanation of the 'Italian' pattern provided by Elson cannot be correct does not, of course, necessarily disprove the notion that 'Italian' might yet somehow represent the 'Proto-East-Romance' norm, from which Romanian allegedly deviates. However, and once again, a cursory glance at the comparative dialectological data beyond Italian (or Tuscan) is enough to reveal a truly fatal problem for the claim that the particular distributional pattern of Romanian is a deviation from the norm. Elson's analysis is simply back-to-front: it is Italian that is 'abnormal', while the pattern found in Romanian is actually normal not just for 'East' Romance, but for the Romance languages generally.

The Romance languages virtually never show YE palatalization in the root-final consonant of the third person plural present indicative (regardless of whether the ending continues Latin -ENT or -UNT), except in Tuscany, Lazio, Umbria, and the Marche, where an (originally) palatalized alternant regularly appears (or appeared historically) before the reflex of -UNT. In Italo-Romance the continuant of -UNT may be discernible as an ending conserving a back vowel (-o(n)-, -u(n)-, etc.), and/or in a metaphonically raised or diphthongized vowel showing the effects of an original ${ }^{*}-\mathrm{u}(\mathrm{n})$. Using these criteria, while we find the palatalized alternant or its reflex in the first person singular present indicative, there is no sign of it in the third person plural present indicative in, for example, AIS maps 1691, 1693, 1694, 1695 (data in Table 7a-e) or Vignoli $(1911 ; 1920 ; 1925)$ for the Lazio dialects of Amaseno, Veroli, and Castro dei Volsci (data in Table 7). The parallels with the distribution found in Romanian are also given for the relevant verbs. 
TABLE 7 Yod effect palatalization in the first person plural present indicative, but not in the third person plural present indicative, in central and southern Italo-Romance dialects

(a) Verb 'to come'

\begin{tabular}{|c|c|c|}
\hline & 1SG.PRS & 3PL.PRS \\
\hline Scanno, Abruzzo & 'vjeygə & 'vje:nanว \\
\hline Trevico, Campania & veyk & 'vjennə \\
\hline Vernole, Puglia & 'єnu & 'E:nune \\
\hline San Chirico Raparo, Basilicata & 'veygu & 'vje:ninu \\
\hline Mistretta, Sicily & vi'enu & vi'e:nu \\
\hline \multirow{2}{*}{$\begin{array}{l}\text { cf. old Romanian } \\
\text { (b) Verb 'to want' }\end{array}$} & viiu & vinu \\
\hline & 1SG.PRS & 3PL.PRS \\
\hline Ruvo, Puglia & 'vwöja & 'vwolana \\
\hline Vernole, Puglia & 'sКu & 'o:lune \\
\hline Catenanuova, Sicily & 'vwöju & 'vwolinu \\
\hline \multirow{2}{*}{$\begin{array}{l}\text { cf. old Romanian } \\
\text { (c) Verb 'to know' }\end{array}$} & voiu & voru \\
\hline & 1SG.PRS & 3PL.PRS \\
\hline Ruvo & 'satto & 'sapənə \\
\hline Carovigno & 'sattfu & 'sapunu \\
\hline \multirow{3}{*}{$\begin{array}{l}\text { Vernole } \\
\text { (d) Verb 'to do' }\end{array}$} & 'sattfu & 'sapune \\
\hline & & \\
\hline & 1SG.PRS & 3PL.PRS \\
\hline Carovigno & 'fattsu & 'fakunu \\
\hline Vernole & 'fattsu & 'fakune \\
\hline \multirow{2}{*}{$\begin{array}{l}\text { cf. old Romanian } \\
\text { (e) Verb 'to see' }\end{array}$} & $(f a c u)$ & facu \\
\hline & 1SG.PRS & 3PL.PRS \\
\hline Serracapriola, Puglia & 'vaja & 'vedənə \\
\hline Trevico, Campania & $v \varepsilon \chi$ & 'virana \\
\hline Avetrana, Puglia & ' $\varepsilon \int u$ & 'Etinu \\
\hline Acri, Calabria & 'viju & 'viðuði \\
\hline Catenanuova, Sicily & 'viju & 'viðinu \\
\hline \multirow{2}{*}{$\begin{array}{l}\text { cf. old Romanian } \\
\text { (f) Verb 'to please' }\end{array}$} & văzu & $v a \breve{d u}$ \\
\hline & 1SG.PRS & 3PL.PRS \\
\hline
\end{tabular}


TABLE 7 Yod effect palatalization in the first person plural present indicative, but not in the third person plural present indicative, in central and southern Italo-Romance dialects (cont.)

\begin{tabular}{|c|c|c|}
\hline & 1SG.PRS & 3PL.PRS \\
\hline Amaseno, Lazio & 'pjatjo & 'pjakənə \\
\hline Veroli, Lazio & 'pjato & $\begin{array}{l}\text { 'pjatanə / } \\
\text { 'pjakunə23 }\end{array}$ \\
\hline Castro dei Volsci, Lazio & 'pjatjo & $\begin{array}{l}\text { 'pjakunə / } \\
\text { 'pjatəпә }\end{array}$ \\
\hline cf. old Romanian & (placu) & placu \\
\hline
\end{tabular}

The situation is overwhelmingly the same for the Romance varieties of northern Italy and for the Gallo-Romance ${ }^{24}$ and Ibero-Romance domains. The AIS data-sets mentioned above, for example, show that palatalized alternants do not generally occur in the present indicative third person plural, whether that form continues Latin-ENT or -UNT.

In sum, judicious assessment of easily available comparative evidence makes it plain that the pattern of alternation purportedly peculiar to Romanian within the alleged 'Proto-East-Romance' family is not in the least limited to Romanian: it is actually the general Romance pattern. What really needs explaining is the real 'deviant'-Italian (and neighbouring central ItaloRomance dialects): for a partial explanation of the Italian facts, see Maiden (2020). The fact that there is nothing special about the Romanian pattern fundamentally undermines Elson's assumption that this pattern must be explicable by something distinctive of Romanian, namely contact with Slavonic. Of course it remains conceivable that Bulgarian influence somehow 'reinforced' the Romance pattern in Romanian, even if it did not cause it, but the insurmountable problem is that we simply cannot tell.

23 Cf. also old Neapolitan piacuno (Ledgeway, 2009: 376f.).

24 See, e.g., Anglade (1921: 289, 333, 345, 347f., 351f.) for old Occitan. AIs map 1695 shows possible evidence for this type in the reflex of UEniunt 'they come' in the FrancoProvençal of Brusson and Ronco Canavese, but there are no other examples. There is also some occasional evidence from the Romansh dialects of the lower Engadine for the iotacized alternant in third person plurals (see Decurtins, 1958: 133, 145, 186). Two otherwise completely isolated exceptions from the AIs showing apparent YE palatalization in the third person plural present indicative are Acri (Calabria), with 1SG.PRS.IND 'vieju 'come' 3PL.PRS.IND 'vjeninu, and Spinazzola (Puglia), with 1SG.PRS.IND 'vajfə 'see' 3PL. PRS.IND 'vefənว. 
Finally, there is a suggestive fragment of philological evidence. Mihăescu (1960: 142, 244) finds facunt, for expected faciunt, in an inscription from Aquincum (Pannonia Inferior). Unfortunately, we lack the corresponding first person singular present indicative or the present subjunctive forms-so we cannot tell for sure whether facunt was part of exactly the alternation pattern found in Romanian ${ }^{25}$-but if Mihăescu is correct in identifying it as the precursor of Romanian $f a c(u)$, then the hypothesis that the latter reflects Slavonic influence becomes untenable, given that no datable inscription from Aquincum is later than AD 377 (Mihăescu, 1960: 27), and that the town is known to have been abandoned by the beginning of the fifth century.

\section{The Romanian Alternation Patterns are Less Like those of Middle Bulgarian than they Seem}

There remains a further problem, reflecting my criterion (ii), above, in that the Romanian data actually seem unlike the Bulgarian data in a respect that Elson effectively passes over. ${ }^{26}$ Exactly the same paradigmatic distributional pattern resulting from iotacization is to be found in old Romanian verbs with original root final $-\mathrm{n}$ and $-\mathrm{l}$, as well as those in root-final dentals: e.g., viu (< *'venjo) 'I come' (3PL vinu), saiu (< *'saljo) 'I jump' (3PL saru). Despite Elson's claim to the contrary, radical-final -n, at least, occurs in Romanian anything but infrequently. He does acknowledge this iotacization of nasals and laterals, among other consonants, (2017: $851 \mathrm{n} 18)$, only to dismiss it from consideration, claiming that the details 'do not contribute to [his] discussion'. One

25 Expected prevocalic I is absent in a number of other words in inscriptions from this area (Mihăescu, 1960: Section 67), so we cannot be certain that facunt is a case of particular absence of the expected outcome in the third person plural present indicative. See also Ionescu-Ruxăndoiu (2018: 182).

26 They are also different in respect of their paradigmatic distribution, in that the Romanian alternants at issue also occur in the third person forms of the present subjunctive and in the gerund, categories for which no direct counterpart can be found in middle Bulgarian. These facts are not, however, necessarily incompatible with the hypothesis of middle Bulgarian influence, given the robust and recurrent patterns of identity between the relevant present-tense alternants and the subjunctive and gerund which independently exist in Romanian (as Elson, 2017: 872f. acknowledges, at least as far as the subjunctive is concerned), which could have served as templates for the paradigmatic distribution of the 'Bulgarian' alternation type if it originated in the present tense. On this, the reader is further referred to Elson (2017: 871-878), who appears however unaware of different analyses of these phenomena by Maiden (1996a; 2011a,b; 2013a); see also Maiden (2018: 99f.). 
reason given is that 'in the case of nasals and liquids, palatalization occurs in conjunction with other changes which eliminated its reflex'. But if this outcome, phonologically very different from what we see in middle Bulgarian, nonetheless displays the paradigmatic distribution at issue, then we have a serious potential counterexample to Elson's claim of Bulgarian influence on the paradigmatic outcome in Romanian, and the facts should therefore have been carefully examined. As it happens, those facts actually could be reconciled with the 'Bulgarian' hypothesis. The historically underlying alternants in Romanian are palatal consonants $[\mathrm{n}]$ and $[K]$ (see, e.g., Sala, 1976: 228-230), and these might, in principle, have been associated by speakers with the middle Bulgarian palatalized nasals and liquids which also occurred in the relevant morphological environments (cf. Leskien, 1922: $5^{2}$ for old Bulgarian). However that may be, here we see, once again, the need for due diligence in exploring of all the available comparative-historical data.

Elson (2017: 888) criticizes 'a strong tendency among linguists to interpret such compositional changes as the result of non-phonetic innovation in the form of analogy, i.e., as the result of system-internal innovation with no regard to the defensibility of its invocation (i.e., whether there was an existing pattern which might have served as the basis for the changes in phonemic composition)'. In the absence of such an existing pattern, he says, we may legitimately appeal to contact as an explanation. This is a mistake: the onus remains on the proponent of a contact-based explanation convincingly to rule out the possibility of an internal motivation, and in the case of the alternation type in (Table 8) that is not so easy to do.

The alternation-type in Table 8 is merely similar to Bulgarian, while it is exactly like, in phonological content and paradigmatic distribution, ${ }^{27}$ an existing, native, Daco-Romanian pattern. This latter is entirely attributable to the effects of regular Romance palatalization and affrication of velars before front vowels. Moreover, the pattern seen in Table 8 is a typically Romance development, with counterparts in other Romance languages. Consider, first, the Romanian verbs a zice 'say' and a merge 'go', where the alternation $[\mathrm{k}] \sim[\mathrm{t}]$, and $[\mathrm{g}] \sim\left[\mathrm{d}_{3}\right]$ are regular results of sound change (Table 9 ).

27 At least in respect of the present indicative and the subjunctive. There are some differences in other tenses but it is, after all, the present which is the focus of Elson's attention and the locus of alleged middle Bulgarian influence. 
TABLE 8 Velar palatal alternations in the present tense of the Romanian verb

\begin{tabular}{llll}
\hline 1SG.PRS.IND & 3SG.PRS.IND & 3PL.PRS.IND & 3SG/PL.SBJV \\
\hline$f a[\mathrm{k}]$ 'do' & $f a[\mathrm{t}] \mathrm{e}$ & $f a[\mathrm{k}]$ & $f a[\mathrm{k}] \breve{a}$ \\
$f u[\mathrm{~g}]$ 'flee' & $f u[\mathrm{~d}]] e$ & $f u[\mathrm{~g}]$ & $f u[\mathrm{~g}] \breve{a}$ \\
\hline
\end{tabular}

TABLE 9 Regular morphological consequences of Latin palatalization of velars before front vowels in the Romanian present and subjunctive

\begin{tabular}{|c|c|c|c|c|c|c|c|}
\hline \multicolumn{4}{|l|}{ Latin } & \multicolumn{4}{|c|}{ Romanian } \\
\hline 1SG.PRS & 3SG.PRS & 3PL.PRS & 3SBJV & 1SG.PRS & 3SG.PRS & 3PL.PRS & 3SBJV \\
\hline DICO & DICIT & DICUNT & $\operatorname{DICA}(\mathrm{N}) \mathrm{T}$ & $>z i[\mathrm{k}]$ & $z i[\mathrm{t}] e$ & $z i[\mathrm{k}]$ & $z i[\mathrm{k}] \breve{a}$ \\
\hline MERGO & MERGIT & MERGUNT & $\operatorname{MERGA}(\mathrm{N}) \mathrm{T}$ & $>\operatorname{mer}[\mathrm{g}]$ & $\operatorname{mer}\left[\mathrm{d}_{3}\right] e$ & $\operatorname{mer}[\mathrm{g}]$ & mear $[\mathrm{g}] \breve{a}$ \\
\hline
\end{tabular}

Taking into account the special behaviour of the third person plural present, as discussed in Section 5, this pattern for palatalization of velars before front vowels is exactly the same as that historically predictable for YE. Both types of verb have in common the alternations 3SG [t] $\sim 3 P L[k]$ and 3SG [d] $\sim 3 \mathrm{PL}[\mathrm{g}]$, as shown in Table (10). It is therefore not true to say, as Elson (2017: 868 ) does, that there exists for such a development 'no motivation internal to Romanian as a function of the structural details of its conjugation'. The relevant motivation simply does exist, independently of any possible 'Bulgarian' influence. Nor does it seem valid to assert that 'we cannot claim that verbs of the E conjugation and the $\breve{\mathrm{E}} / \mathrm{I}$ complex, in which a reflex of yotation is expected but absent (e.g., tăc-ea), were analogized to those of the $\breve{\mathrm{E}}$ conjugation in which a reflex is not expected (e.g., zic-e) because this would leave us without motivation for parallel evolution among verbs with radical-final dental (e.g., ved-ea, etc. were not analogized to cred-e etc.).' Elson's formulation is obscure, but he appears to mean lack of parallel evolution in verbs such as vedea, because verbs with the root-final dentals do not show the development alleged to have affected verbs with root-final velars. Yet this argument would only apply by assuming that the relevant changes predated the emergence of the palatal velar alternations mentioned above, which are unparalleled in verbs with root-final dentals.

Even if there is no need to appeal to putative 'middle Bulgarian' influence in this case, might one not still invoke it to explain the direction of the analogical 
change?28 Why do we not get 1SG.PRS **faț 3SG.PRS face and 1SG.PRS **zit $\sim$ 3SG.PRS zice rather than the actually occurring fac $\sim$ face and zic $\sim$ zice - that is, why do we not get a situation in which the historically expected changes effected by yod occur in reflexes of FACIO, and are then analogically extended to verbs such as DICO? Could this be because this latter pattern does not have a counterpart in Bulgarian, while the opposite and actually occurring one does occur there? Such an explanation might have some traction (although it would be impossible to prove), were it not for the fact that what we observe in Romanian is also observed independently in other Romance languages while, to the very best of my knowledge, the putative opposite development considered above is found absolutely nowhere in Romance. For more extensive illustration of these facts see, e.g., (Maiden, 2018: 93-122). Consider, for example, the velar of Spanish 1SG.PRS.IND hago 1/3SG.PRS.SBJv haga vs the historically underlying yod whose effects are still seen in Portuguese faço $\sim$ faça (< Lat. FACIO FACIAT), Italian 1SG.PRS.IND fuggo 3PL.PRS.IND fuggono $\sim 1 / 3$ SG.PRS.SBJV fugga with the velar, for older fuggio $\sim$ fuggiono $\sim$ fuggia showing the historically regular alternation (FUGIO FUGIUNT FUGIAT). The Romanian substitution of velar for affricate alternants in such cases conforms to a widespread Romance development. Yes, it rather resembles Bulgarian, but how can we know that the resemblance is anything other than coincidental?

We may add to the three mentioned in Section 2.2 a fourth criterion of plausibility in arguing for contact effects. The verisimilitude of the claim that some phenomenon $\mathrm{X}$ in language $\mathrm{R}$ is due to contact with language $\mathrm{B}$ increases if there are in $\mathrm{R}$ several other phenomena of a similar kind that incontrovertibly come from B; that is, if $\mathrm{X}$ is part of a 'cluster' of similar phenomena. The 'Bulgarian hypothesis' regarding YE could be seen as plausible in a general way because it is not the only alleged Bulgarian 'organizational' influence on Romanian (see, e.g., Elson, 1994; 1999), and this is why Elson argues (2017: 890) that ' $[w]$ e may therefore see, in support of Bulgarian influence in the Romanian present system, a general tendency for the importation of Bulgarian organization into Romanian verbal morphology [...]'. But what is the status of the other cases which constitute this 'general tendency'? I limit myself to morphological

28 Note Thomason's observation that 'a growing body of evidence suggests that multiple causation - often a combination of an external and one or more internal causes - is responsible for a sizable number of changes' (Thomason, 2010: $3^{2}$ ). 
TABLE 10 Morphological parallels between the effect of yod and the palatalization of velars before front vowels in Romanian

\begin{tabular}{|c|c|c|c|c|c|c|c|c|}
\hline \multicolumn{5}{|l|}{ Latin } & \multicolumn{4}{|c|}{ Romanian } \\
\hline 1SG.PRS & 3SG.PRS & 3PL.PRS & 3SBJV & & 1SG.PRS & 3SG.PRS & 3PL.PRS & 3SBJV \\
\hline DICO & DICIT & DICUNT & $\operatorname{DICA}(\mathrm{N}) \mathrm{T}$ & $>$ & $z i[\mathrm{k}]$ & $z i[\mathrm{t}]] e$ & $z i[\mathrm{k}]$ & $z i[\mathrm{k}] \breve{a}$ \\
\hline MERGO & MERGIT & MERGUNT & $\operatorname{MERGA}(\mathrm{N}) \mathrm{T}$ & $>$ & $\operatorname{mer}[\mathrm{g}]$ & $\operatorname{mer}\left[\mathrm{d}_{3}\right] e$ & $\operatorname{mer}[\mathrm{g}]$ & mear $[\mathrm{g}] \breve{a}$ \\
\hline FACIO & FACIT & FACIUNT & $\operatorname{FACIA}(\mathrm{N}) \mathrm{T}$ & $>$ & $(f a[\mathrm{k}])$ & $f a[\mathfrak{t}]] e$ & $f a[\mathrm{k}]$ & $f a[\mathrm{k}] \breve{a}$ \\
\hline FUGIO & FUGIT & FUGIUNT & FUGIA $(\mathrm{N}) \mathrm{T}$ & $>$ & $(f u[\mathrm{~g}])$ & $f u\left[d_{3}\right] e$ & $f u[g]$ & $f u[\mathrm{~g}] \breve{a}$ \\
\hline
\end{tabular}

phenomena in Romanian which can be viewed as 'morphomic', in that they involve characteristics of the abstract organization of inflexional paradigms to which no coherent function or meaning can be ascribed. ${ }^{29}$

Elson (2017: 871) argues that another reflexion of Bulgarian influence in Romanian is that here, unlike (nearly) all other Romance languages, root-final velars in first conjugation verbs undergo phonologically regular palatalization before inflexional front vowels. Thus, while Romanian, Italian, and Spanish all behave in the same way in showing the expected alternations arising from palatalization in non-first conjugation verbs (e.g., 3SG.PRS.IND Ro. $z i[\mathrm{t}]]$, It.

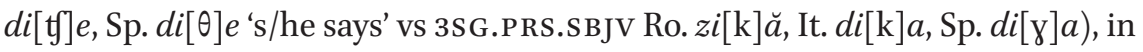
the first conjugation only Romanian shows the type of alternation expected on historical phonological grounds, while other Romance languages do not (e.g.,

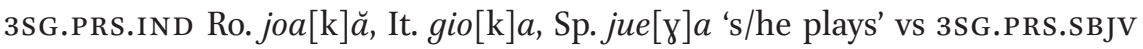
Ro. joa $[\mathrm{t}]]$, It. gio $[\mathrm{k}] i, \mathrm{Sp} . j u e[\mathrm{\gamma}] e$ ). For Elson, these facts are clear evidence of Bulgarian influence, because Bulgarian, unlike the sister Romance languages of Romanian, imposes no conjugational restriction on palatalization. Yet in fact, Romanian merely behaves in the normal and historically predictable way, and there is nothing to be 'explained'. At most one might say that this differentiated behaviour on the part of Romanian is yet another linguistic manifestation of the early isolation of its speakers from the main body of Romance languages

29 For discussion of another possible candidate for Slavonic morphological influence on the organization of Romanian morphology, namely the truncation of the infinitive such that the 'short' form has the value of a verb, and the 'long' form that of a noun, see, e.g., Petrucci (1999: 128f.). The truncation itself is a widespread Romance phenomenon, and cannot be attributed to any parallel development in Bulgarian. Petrucci suggests that the Romanian pattern was mapped onto the meaning of the Bulgarian distinction between 'long' and 'short', but here we are dealing with concrete expression of distinctions of grammatical meaning, rather the kind of more abstract organizational phenomenon with which this study is concerned. 
- an isolation in which the Slavic incursions, rather than the Slavonic languages themselves, did of course play a role. What actually needs to be explained is why the other Romance languages do impose a conjugational restriction on palatalization (see, on this, Maiden, 2018: 277-283), not why Romanian does not. In fact, this behaviour of the Romanian first conjugation is not the only respect in which Romanian differs from other Romance languages in the sense of a greater phonological propensity to palatalize velars. This is not the place to explore the issues, but for discussions see Skok (1926), Merlo (2014), or Maiden (2019: 110f.).

Another case of arguably 'morphomic' influence of Bulgarian on Romanian is addressed in Elson (1999). He observes that Romanian retains from Latin a morphologically distinct subjunctive form only in the third person, the subjunctive forms of all other persons having been replaced (in nearly all verbs) by those of the present indicative (Table 11). Elson attributes this fact to structural influence from Bulgarian. But Bulgarian does not have a morphological subjunctive, and so he actually locates the similarity with the Romanian subjunctive in the Bulgarian imperative (and more precisely in the first conjugation imperative). Note that the subjunctive marking in Romanian involves a kind of 'reversal' of the inflexional ending such that the subjunctive ending of first conjugation verbs (such as a zice 'to say') is identical to the third person singular ending of the present of a cânta, and vice versa. Given the complexity of Elson's analysis, it is easiest to quote from it verbatim (Elson, 1999: 147).

The characteristics of the imperative - a single form unmarked morphologically for person/number, and canonically identical to forms of the present but opposed to them by a realization of the nonterminal suffix characteristic of the present of another conjugation - are exactly those characteristics of the Romanian subjunctive with respect to the indicative. Thus the relationship of veda [an exemplar of the Bulgarian first conjugation, $\mathrm{MM}$ ] to its imperative in Bulgarian is identical to that of all verbs to their subjunctive in Romanian [...]. When, to these formal identities, we add that, in each language, one of the paradigms in question (i.e., the present) is indicative, and the other (i.e., the subjunctive in Romanian and the imperative in Bulgarian) is modal, and that, in each language, the indicative and modal paradigms are not only desinentially identical to each other, comprising a nonterminal, vocalic suffix which may be followed by a terminal consonantal one, but that the present and imperative in each are opposed to past paradigms in lacking an overt marker of tense, which the past paradigms possess, the possibility of innovation 
TABLE 11 Limitation of distinctive present subjunctive morphology to the third person in Romanian

\begin{tabular}{|c|c|c|c|c|c|c|}
\hline Latin & $1 S G$ & $2 \mathrm{SG}$ & $3 S G$ & $1 P L$ & $2 \mathrm{PL}$ & $3 P L$ \\
\hline IND & CANTO 'sing' & CANTAS & CANTAT & CANTAMUS & CANTATIS & CANTANT \\
\hline SBJV & CANTEM & CANTES & CANTET & CANTEMUS & CANTETIS & CANTENT \\
\hline IND & DICo 'say' & DICIS & DICIT & DICIMUS & DICITIS & DICUNT \\
\hline SBJV & DICAM & DICAS & DICAT & DICAMUS & DICATIS & DICANT \\
\hline \multicolumn{7}{|c|}{ Romanian } \\
\hline & $1 S G$ & $2 S G$ & $3 S G$ & $1 P L$ & $2 \mathrm{PL}$ & $3 \mathrm{PL}$ \\
\hline IND & cânt & cânți & cântă & cântăm & cântați & cântă \\
\hline SBJV & cânt & cânți & cânte & cântăm & cântați & cânte \\
\hline IND & $z i c$ & zici & zice & zicem & ziceți & $z i c$ \\
\hline SBJV & $z i c$ & $z i c i$ & zică & zicem & ziceți & zică \\
\hline
\end{tabular}

internal to Romanian as an explanation for the loss of the personal forms in its subjunctive ceases to be a serious alternative. There can be little doubt that we are justified in claiming that Romanian calqued the formal pattern of relationship between the present indicative and the imperative of first conjugation verbs in Bulgarian by adopting the single characteristic which distinguished it from Bulgarian in this regard, i.e., a reduced modal paradigm comprising only a third person form. It did this by abandoning personal forms of the plural subjunctive. [My emphasis]

Elson's analysis contains an obvious petitio principii, since the very thing which needs to be demonstrated, namely Bulgarian influence, is tacitly assumed. The assumption seems to be that if no internal motivation for some phenomenon is detectable, then it is legitimate to invoke language contact. The task then becomes, in this case, one of finding something in Bulgarian that-in the absence of anything that really resembles the Romanian situation-looks at least rather like the Romanian facts and might just about explain them, given sufficient $a d$ hoc adjustments. Yet the onus on anyone appealing to language contact in order to explain some linguistic change is first to exclude beyond reasonable doubt the possibility of an internal development, and this Elson does not do. The presence of forms identical to the indicative in three of the four Romanian paradigm-cells at issue is eminently consistent with much more widespread Romance developments. There is in fact an extensive Romance tendency for indicative forms to replace present subjunctive forms, particularly in the first and second persons plural, and this is systematically 
observable in many Italo-Romance varieties, ${ }^{30}$ as demonstrated in detail by, for example, Maiden (2010: 133-135; 2012: 33-35, 45-47). Romanian second person singular subjunctives are overwhelmingly identical ${ }^{31}$ to the corresponding present indicative forms by virtue of ending in $-i$ (e.g., 2SG.PRS. IND vezi 'see' = 2SG.SBJV vezi; 2SG.PRS.IND dormi 'sleep' = 2SG.SBJV dormi; $\mathrm{cf}$. Latin UIDES - UIDEAS, DORMIS - DORMIAS). Elson interprets this as evidence of replacement of the subjunctive form by that of the present indicative, but one could equally say that Romanian has generalized $-i$ as second person singular marker in both moods and all tenses (only certain imperatives escape this generalization). Elson (1999: 145) is aware of this possibility, but argues against it on the grounds that 'Italian'-this language again being somehow elevated to the undeserved status of proxy for all eastern Romance-has a second person singular present subjunctive ending in - $a$ (e.g., 2SG.PRS.SBJV veda 'see'; dorma 'sleep'), not in $-i$. But here he is anachronistically projecting onto an entire branch of the Romance languages a relatively recent innovation of Italian. Historically, Italian itself with much of the rest of Italo-Romance had a second person singular present subjunctive ending $-i$ (or $-e$ ), not $-a$ (see, e.g., Rohlfs, 1968: 296f., 299-301; Maiden, 1995: 129; 1996b: 161). Once again, the drawbacks of too limited a historical and comparative perspective are all too evident.

Only the behaviour of the first person singular, in the above case, remains as not obviously explicable in terms of these internal (Romance and Romanian) developments, but in a system where both second person forms, and one first person form, are already identical to the indicative, it is not surprising that the first person singular may follow suit. If the third person is more resistant, this fact can probably be attributed to the very high frequency of occurrence of the third person (yet note that in some Daco-Romance varieties such as IstroRomanian even the third person subjunctive is replaced by indicative forms: cf. Kovačec, 1971: 150). If appeal to internal developments may not deliver a completely satisfying account of the morphology of the Romanian subjunctive, it very nearly does so - and this is enough to make any appeal to Bulgarian influence look very shaky. In any case, the entire argument from the Bulgarian imperative-in fact solely from the Bulgarian first conjugation imperative-is implausible, perhaps most of all because one might expect the Bulgarian imperative to map functionally onto its obvious counterpart, namely the Romanian imperative. Since imperative and subjunctive morphology are clearly distinct in Romanian, it is hard to see why structures specific to imperatives would be

30 Elson (1999: 144) acknowledges this fact, yet dismisses its significance.

$3^{1}$ In only very few verbs is there a subjunctive root allomorph distinct from the indicative. 
taken to apply instead to subjunctives. Appeal to Bulgarian influence in this case does not in fact seem anything like a 'serious alternative', and it is certainly not such if we take into account my criterion (ii) in Section 2.2, namely that cogent claims for contact effects will involve structures in both of the languages in contact which are maximally similar. To say that there is 'little doubt' of Bulgarian influence is wrong. ${ }^{32}$

I am very open to the proposition that 'realizational', or more specifically, 'morphomic', patterns of allomorphy might be borrowed from one language to another. If the Romanian data could have been made to show this, a significant and original addition would have been made to the theory of morphological change in diachrony. But if theoretically significant claims are to be made about the role of contact in morphological change, and are to have scientific validity, suitably rigorous conditions must be met in order to guarantee that the phenomena at issue are not independent of contact. Alas, the relevant phenomena as discussed in Elson (2017) turn out not to be in the least unique to Romanian among the Romance languages, and 'Bulgarian' influence remains therefore at best undemonstrable. Romanian morphology unquestionably is, in some respects, 'Slavonic', but it remains to be convincingly shown that it is in any way 'Slavonic' at the level of purely morphological paradigmatic organization of the kind in which I am interested.

32 I have not mentioned Elson's argument (Elson, 1994) that Romanian has calqued from Bulgarian 'a characteristic organizational feature of many Bulgarian verbs: morphological relationship between the preterite and the participle (i.e., the occurrence in each of a morpheme expressing the grammatical meaning common to them)' (Elson, 1994: 27). It needs to be said that the tendency analogically to ascribe the same stem allomorph to both the preterite and the past participle is far from unique to Romanian among the Romance languages (see, e.g., Meyer-Lübke, 1895: 372, 413, 419, 426; Nyrop, 196o: 127, 77f., 87, 140; Rohlfs, 1968: 369f., 373-375). Nonetheless, this tendency does seem to me far more extensive and systematic in Romanian-where nearly all preterites and past participles have the same stem-than elsewhere in Romance. Could Bulgarian influence be at work here? It might be (perhaps 'reinforcing' a general Romance tendency?). However, from the point of view of the particular kind of phenomenon I am interested in here, namely potential transfer of 'morphomic' phenomena by contact, this case does not qualify. The distribution of the relevant stem allomorph in Romanian actually is morphomic (for reasons set out at length in Maiden (2013b) - for example that the supine is also affected), but as I understand it the original relevant pattern in Bulgarian would not qualify as 'morphomic' in my sense, since it expressed a 'common grammatical meaning' (namely perfectivity) present in both the preterite and the participle. 
Some other general methodological points also emerge from the foregoing. One is that absence of evidence should not be taken for evidence of absence. There is a frustratingly large amount of the former in Romanian-given that the first thousand years or so of the history of the language are veiled in obscurity-and it is rash to appeal too readily to contact as an explanation of phenomena whose internal context and motivation we cannot immediately discern (cf. Elson, 1999:146; 2017: 868, on this point). ${ }^{33}$ We also urgently need to form a clear idea of the historical circumstances of any linguistic contact-something which in the case of Romanian is again difficult. The contact effects in Romanian morphology identified by Elson are of such structural complexity and abstractness that I at first assumed that his argument must be that these effects emerged in the minds of native bilinguals or, possibly, in the minds of adult Bulgarian speakers acquiring Romanian. Surprisingly, however, Elson (1999:151) argues that the changes he describes in Romanian subjunctive morphology must have been made by Romanian-speaking non-native 'borrowers' of Bulgarian forms, who had an apparently imperfect knowledge of Bulgarian paradigmatic morphology. This idea is, to say the least, puzzling: why would non-Bulgarian-speaking Romanian speakers set about remodelling their native (and differently structured) inflexional morphology on the basis of partial similarities with the structural idiosyncrasies of a language they did not really know? The fundamental point here is that if we are to assess possible Slavonic influences on Romanian morphology, we first need a clearer understanding than we presently have of the circumstances and dynamics of the contact (cf. also Elson, 2017: 891).

I have repeatedly insisted in this study that for a cogent demonstration of assumed effects of language contact we need a properly detailed comparative and historical knowledge of all the languages in play. This exposes me to the justifiable charge that I myself have an inadequate grasp of the history of Bulgarian and other Slavonic languages. I have depended here almost entirely on Elson's account of the historical Bulgarian facts, which I have been happy to take on trust. I have no doubt, however, that my analysis would have benefited from a proper training in the Slavonic data. In reality, very few linguists working on contact can ever hope to have equally deep comparative-historical knowledge of languages belonging to different language-families (and whatever the defects of Elson's arguments in this case, his ability to span Slavonic and Romance remains unusual and admirable). I suggest, therefore, that for work on contact between languages belonging to different families to be truly

33 On the other hand we should not assume, either, that the apparent availability of an internal motivation automatically rules out an effect of contact, where a robust case for the latter could be constructed. 
of value it will not only have to satisfy the general criteria of plausibility I have set out here, but it will also be the result of close collaboration between scholars with complementary expertise in the relevant languages.

\section{References}

AIS = Jaberg, Karl and Jakob Jud. 1928-1940. Sprach- und Sachatlas Italiens und der

Südschweiz. Zofingen: Ringier.

Anglade, Joseph. 1921. Grammaire de l'ancien provençal. Paris: Klincksieck.

Aronoff, Mark. 1994. Morphology By Itself. Cambridge, MA: MIT Press.

Ascoli, Graziadio. 1881-1882. Lettere glottologiche. Prima lettera. Rivista di Filologia e d'Istruzione Classica 10: 1-71.

Bossong, Georg. 2016. Classifications. In Adam Ledgeway and Martin Maiden (eds.), The Oxford Guide to the Romance Languages, 63-72. Oxford: Oxford University Press.

Decurtins, Alexi. 1958. Zur Morphologie der unregelmässigen Verben im Bündnerromanischen. Bern: Francke.

Dragomirescu, Adina. 2015. Are there Slavonic features in the syntax of Romanian?

Two case studies. Diacronia 1: 1-13.

Elson, Mark. 1994. Slavic influence on the organization of Romanian conjugation. Indiana Slavic Studies 7: 27-35.

Elson, Mark. 1999. Slavic influence in the evolution of the Romanian subjunctive. Zeitschrift für Balkanologie 35: 139-152.

Elson, Mark. 2017. On the history of radical-final palatalization in Romanian conjugation: The interaction of phonetic phenomena with non-phonetic. Zeitschrift für romanische Philologie 133: 844-892.

Fanti, Renata. 1939. Note fonetiche e morfologiche sul dialetto di Ascrea. L'Italia dialettale 15: 101-133.

Friedman, Victor. 2009. The diffusion of Macedonian inflections into MeglenoRomanian: A reconsideration of the evidence. In Steven Franks, Vrinda Chidambaram , and Brian Joseph (eds.), A Linguist's Linguist. Studies in South Slavic Linguistics in Honor of E. Wayles Browne, 223-233. Bloomington: Slavica.

Gardani, Francesco. 2018. On morphological borrowing. Language and Linguistics Compass 12. DOI: 10.1111/lnc3.12302.

Gardani, Francesco, Peter Arkadiev, and Nino Amiridze. 2015. Borrowed morphology: An overview. In Francesco Gardani, Peter Arkadiev, and Nino Amiridze (eds.), Borrowed Morphology, 1-23. Berlin: De Gruyter Mouton.

Harris, Martin. 1988. The Romance languages. In Martin Harris and Nigel Vincent (eds.), The Romance Languages, 1-25. London: Routledge. 
Hurren, Antony. 1969. Verbal aspect and archi-aspect in Istro-Romanian. La Linguistique 2: 59-9o.

Ionescu-Ruxăndoiu, Liliana. 2018. In Marius Sala and Liliana Ionescu Ruxăndoiu (eds.), Istoria limbii române I, 170-188. Bucharest: Univers Enciclopedic Gold.

Kossmann, Maarten. 2015. Contact-induced change. In Matthew Baerman (ed.), The Oxford Handbook of Inflection, 251-271. Oxford: Oxford University Press.

Kovačec, August. 1971. Descrierea istroromânei actuale. Bucharest: Editura Academiei. Ledgeway, Adam. 2009. Grammatica diacronica del napoletano. Tübingen: Niemeyer. Leskien, Adam. 1922. Handbuch der altbulgarischen (altekirchenslavischen) Sprache. Heidelberg: Winter.

Loporcaro, Michele and Tania Paciaroni. 2016. The dialects of central Italy. In Adam Ledgeway and Martin Maiden (eds.), The Oxford Guide to the Romance Languages, 228-245. Oxford: Oxford University Press.

Maiden, Martin. 1991. Interactive Morphonology. Metaphony in Italy. London: Routledge. Maiden, Martin. 1995. A Linguistic History of Italian. London: Longman.

Maiden, Martin. 1996a. The Romance gerund and system-dependent naturalness in morphology. Transactions of the Philological Society 94: 167-201.

Maiden, Martin. 1996b. On the Romance inflectional endings $-i$ and -e. Romance Philology 50: 147-182.

Maiden, Martin. 2010. Riflessioni comparative e storiche sulla sorte del congiuntivo presente nelle varietà italoromanze. In Giovanni Ruffino and Mari D’Agostino (eds.), Storia della lingua italiana e dialettologia, 129-149. Palermo: Centro di studi filologici e linguistici siciliani.

Maiden, Martin. 2011a. Morphological persistence. In Martin Maiden , John Charles Smith, and Adam Ledgeway (eds.), The Cambridge History of the Romance Languages. I. Structures, 155-215, 699-706. Cambridge: Cambridge University Press.

Maiden, Martin. 2011b. Morphophonological innovation. In Martin Maiden , John Charles Smith , and Adam Ledgeway (eds.), The Cambridge History of the Romance Languages. I. Structures, 216-267, 706-713. Cambridge: Cambridge University Press.

Maiden, Martin. 2012. A paradox? The morphological history of the Romance present subjunctive. In Sascha Gaglia and Marc-Olivier Hinzelin (eds.), Inflection and Word Formation in Romance Languages, 27-54. Amsterdam: John Benjamins.

Maiden, Martin. 2013a. Semi-autonomous' morphology? A problem in the history of the Italian (and Romanian) verb. In Silvio Cruschina , Martin Maiden , and John Charles Smith (eds.), The Boundaries of Pure Morphology:Diachronic and Synchronic Perspectives, 24-44. Oxford: Oxford University Press.

Maiden, Martin. 2013b. The Latin 'third stem' and its Romance descendants. Diachronica 30: 492-530. 
Maiden, Martin. 2016a. Romanian, Istro-Romanian, Aromanian, Megleno-Romanian. In Adam Ledgeway and Martin Maiden (eds.), The Oxford Guide to the Romance Languages, 91-125. Oxford: Oxford University Press.

Maiden, Martin. 2016b. Dalmatian. In Adam Ledgeway and Martin Maiden (eds.), The Oxford Guide to the Romance Languages, 126-138. Oxford: Oxford University Press.

Maiden, Martin. 2016c. Italo-Romance metaphony and the Tuscan diphthongs. Transactions of the Philological Society 114: 198-232.

Maiden, Martin. 2018. The Romance Verb. Morphomic Structure in Diachrony. Oxford: Oxford University Press.

Maiden, Martin. 2019. Alberto Varvaro e la storia «interna» delle lingue romanze. In Laura Minervini (ed.), Filologia letteratura e linguistica di Alberto Varvaro: atti delle giornate di studio, 101-116. Padua: Antenore.

Maiden, Martin. 2020. Un problema trascurato di morfologia storica: la terza persona plurale del presente indicativo nell'italoromanzo. In Patrizia del Puente et al. (eds.), Tra etimologia romanza e dialettologia. Studi in onore di Franco Fanciullo, 245-259. Alessandria: Edizioni dell'Orso.

Malkiel, Yakov. 1991. 'Western Romance' versus 'Eastern Romance': The terms, the images, the underlying concepts. Romanische Forschungen 103: 141-156.

Merlo, Clemente. 1909. Gli italiani amano, dicono e gli odierni dialetti umbroromaneschi. Studii romanzi 6: 69-83.

Merlo, Roberto. 2014. Un problema trascurato di fonetica storica romena: la 'palatalizzazione delle velari' tra eredità latina e interferenze slave. Dacoromania 19: $165^{-197 .}$

Meyer-Lübke, Wilhelm. 1895. Grammaire des langues romanes II. Morphologie. Paris: Welter.

Mihăescu, Haralambie. 196o. Limba latină în provinciile dunărene ale imperiului roman. Bucharest: Editura Academiei Republicii Populare Romîne.

Nyrop, Kristoffer. 196o. Grammaire historique de la langue française II. Morphologie. Copenhagen: Gyldendal.

OVI = Opera del vocabolario italiano. Florence: CNR. http://www.ovi.cnr.it/.

Petrucci, Peter. 1999. Slavic Features in the History of Romanian. Munich: Lincom.

Rohlfs, Gerhard. 1968. Grammatica storica della lingua italiana e dei suoi dialetti: morfologia. Turin: Einaudi.

Rosetti, Alexandru. 1986. Istoria limbii române. Bucharest: Editura științifică și enciclopedică.

Sala, Marius. 1976. Contributions à la phonétique historique du roumain. Paris: Klincksieck. 
Sala, Marius. 2013. Contact and borrowing. In Martin Maiden, John Charles Smith, and Adam Ledgeway (eds.), The Cambridge History of the Romance Languages I. Structures, 187-236. Cambridge: Cambridge University Press.

Skok, Petar. 1926. Zur Chronologie der Palatalisierung von $c g$ qu vor e $i$ y $i \mathrm{im}$ Balkanlatein. Zeitschrift für romanische Philologie 46: 385-410.

Stump, Gregory. 2001. Inflectional Morphology. A Theory of Paradigm Structure. Cambridge: Cambridge University Press.

Thomason, Sarah. 2010. Contact explanations in linguistics. In Raymond Hickey (ed.), The Handbook of Language Contact, 31-47. Oxford: Blackwell.

Väänänen, Veikko. 1963. Introduction au latin vulgaire. Paris: Klincksieck.

Vignoli, Carlo. 1911. Il vernacolo di Castro dei Volsci. Studj romanzi 7:116-296.

Vignoli, Carlo. 1920. Vernacolo e canti di Amaseno. Rome: Società filologica romana.

Vignoli, Carlo. 1925. Il vernacolo di Veroli in provincia di Roma. Rome: Società filologica romana.

Weinreich, Uriel. 1968. Languages in Contact. The Hague: Mouton. 